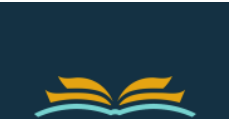

\title{
Pandemi COVID-19 dan Tantangan Kebijakan Kesehatan Mental di Indonesia
}

\author{
ILHAM AKHSANU RIDLO \\ Departemen Administrasi dan Kebijakan Kesehatan, Fakultas Kesehatan Masyarakat Universitas \\ Airlangga
}

\begin{abstract}
ABSTRAK
Kesehatan mental merupakan aspek penting dalam mewujudkan kesehatan yang menyeluruh. Namun di sebagian besar negara berkembang, masalah kesehatan mental belum diprioritaskan. Pandemi Coronavirus-19 (COVID-19) menjadikan kesehatan mental menjadi isu penting bagi dunia. Organisasi Kesehatan Dunia (WHO) mengidentifikasi kesehatan mental sebagai komponen integral dari penanggulangan COVID-19. Pandemi COVID-19 dengan transmisi penularan yang masif dan tingkat kematian yang tinggi menyebabkan masalah yang mengarah pada gangguan mental. Kebijakan kesehatan mental di Indonesia harus mengoptimalkan integrasi layanan kesehatan mental. Pendekatan berbasis masyarakat dapat memperluas cakupan pelayanan kesehatan mental pada masa Pandemi COVID-19. Pemerintah harus mengintegrasikan layanan kesehatan mental ke dalam layanan berbasis masyarakat sebagai cara untuk memastikan cakupan universal pelayanan kesehatan mental. Model pemberdayaan partisipatif dan bottom-up menjadi pilihan yang rasional, untuk mengatasi masalah sumber daya dan stigma sebagai penghalang keberhasilan program kesehatan mental di Indonesia.
\end{abstract}

Kata kunci: kesehatan mental, covid-19, pandemi, kebijakan kesehatan

\begin{abstract}
Mental health is an important aspect in optimizing overall health. However, in most developing countries, mental health issues have not been prioritized. The Coronavirus-19 (COVID-19) pandemic is transforming mental health as an important health issue for the world. The World Health Organization (WHO) identifies mental health as an integral component of tackling COVID-19. The COVID-19 pandemic with its massive transmission and high death rate causes problems that lead to mental disorders. Mental health policies in Indonesia must optimize the integration of mental health services. Community-based approaches can expand the coverage of mental health services during the COVID-19 pandemic. Governments should integrate mental health services into community-based services as a way of ensuring universal coverage of mental health services. Participatory and bottom-up empowerment models are rational choices to address resource issues and stigma as barriers to the success of mental health programs in Indonesia.
\end{abstract}

Keywords: mental health, covid-19, pandemic, health policy 
INSAN Jurnal Psikologi dan Kesehatan Mental, 2020, Vol. 5(2), 155-164, doi: 10.20473/jpkm.v5i12020.155-164 Dikirimkan: 24 Oktober 2020 Diterima: 29 Oktober 2020 Diterbitkan: 2 November 2020

Editor: Atika Dian Ariana

*Alamat korespondensi: Fakultas Kesehatan Masyarakat, Universitas Airlangga, Kampus C Mulyorejo, Surabaya 60115. Pos-el: ilham.ridlo@fkm.unair.ac.id

Naskah ini merupakan naskah dengan akses terbuka dibawah ketentuan the Creative Common Attribution License (http://creativecommons.org/licenses/by/4.0), sehingga penggunaan, distribusi, reproduksi dalam media apapun atas artikel ini tidak dibatasi, selama sumber aslinya disitir dengan baik.

\section{PEN D A H U L U A N}

Sejak ditetapkan sebagai terjadi penularan wabah antar manusia di Wuhan, China pada 31 Desember 2019, infeksi coronavirus-2019 (COVID-19) yang menyebabkan penyakit Severe Acute Respiratory Syndrome - Coronavirus 2 (SARS-Cov-2) menjadi pandemi global. Penularan virus ini ditengarai terkait dengan penjualan daging yang berasal dari binatang liar atau penangkaran hewan di pasar makanan laut (Cui, dkk., 2019). Gejala umum yang didapati oleh pasien adalah demam, batuk dan mialgia atau kelelahan. Gejala yang spesifik yaitu batuk berdahak, sakit kepala, hemoptisis (batuk yang mengandung darah) dan diare. Komplikasi termasuk sindrom gangguan pernapasan akut, cedera jantung akut dan infeksi bakteri sekunder (Huang, dkk., 2020). Sampai saat ini, jumlah informasi tentang virus ini meningkat setiap hari dan semakin banyak data tentang penularan dan rutenya, reservoir, masa inkubasi, gejala dan hasil klinis, termasuk tingkat kelangsungan hidup yang dikumpulkan di seluruh dunia (Corman, dkk., 2020).

Fokus penanganan pandemi COVID-19 di seluruh dunia mengalihkan perhatian masyarakat dari faktor psikososial yang akan ditanggung individu sebagai konsekuensi terjadinya pandemi. Masalah kesehatan mental yang muncul akibat pandemi COVID-19 dapat berkembang menjadi masalah kesehatan yang dapat berlangsung lama dan berpotensi menimbulkan beban sosial yang berat. Status darurat kesehatan masyarakat yang ditetapkan oleh otoritas kesehatan dunia dan dilanjutkan dengan pemberlakuan pembatasan sosial dan isolasi mandiri atau karantina serta membatasi mobilitas masyarakat, berpotensi menimbulkan dampak jangka panjang pada kesehatan mental masyarakat (Gao, dkk., 2020; Pfefferbaum \& North, 2020; Spoorthy, dkk., 2020).

Ukuran dampak pandemi COVID-19 terhadap kesehatan mental belum dapat diukur secara komperhensif, namun informasi mengenai dampak pandemi terhadap kesehatan mental dapat diperkirakan dari temuan penelitian saat wabah MERS-COV pada tahun 2015 di Korea Selatan. Pasien dengan hemodialisis yang harus menjalani hidupnya dalam kondisi terisolasi dilaporkan mengalami peningkatan nilai level hematokrit, kalsium, dan fosfor setelah dua minggu isolasi. Selain itu, dilaporkan juga adanya peningkatan level sirkulasi cell-free genomic DNA (cc-gDNA) dan cell-free mitochondrial DNA (ccf-mtDNA). Beberapa indikator tersebut merupakan indikator stres psikofisik pada manusia. Oleh karena itu, dapat disimpulkan bahwa karantina saat wabah MERS di Korea Selatan dapat menyebabkan peningkatan level stres pada pasien hemodialisis. Dukungan kesehatan umum dan tindak lanjut harus diberikan bahkan enam bulan setelah keluar dari isolasi bagi individu dengan status kesehatan mental yang rentan sebelumnya. Para pasien membutuhkan dukungan yang sesuai termasuk makanan, pakaian dan akomodasi, jika diperlukan (Kim, dkk., 2019) 
Kesehatan mental merupakan aspek penting dalam mewujudkan kesehatan yang menyeluruh. Namun di sebagian besar negara berkembang, masalah kesehatan mental belum diprioritaskan apabila dibandingkan dengan penyakit menular. Regulasi, kebijakan kesehatan mental dan implementasinya di Indonesia masih diikuti oleh kesenjangan yang luas terkait dengan masalah cakupan dan akses pada pelayanannya (Ayuningtyas, dkk., 2018; Ridlo \& Zein, 2015). Pada tahun 2020, Hari Kesehatan Mental Sedunia, yang diperingati pada 10 Oktober 2020, mengambil tema "an opportunity to kick-start a massive scale-up in investment in mental health." World Health Organization (WHO) menekankan pada konsekuensi yang ditimbulkan saat kehidupan kita yang telah banyak berubah akibat pandemi COVID19. Penekanan lain adalah mendorong negara-negara di dunia untuk memberikan perhatian lebih pada kesehatan mental. Sebagai salah satu sektor yang paling terdampak akibat pandemi, kesehatan mental merupakan salah satu bidang kesehatan masyarakat yang paling terabaikan. Padahal, hampir 1 miliar orang hidup dengan gangguan mental, 3 juta orang meninggal setiap tahun akibat penggunaan alkohol yang berbahaya, dan 1 orang meninggal setiap 40 detik karena bunuh diri. Saat ini, miliaran orang di seluruh dunia telah terpengaruh oleh pandemi COVID-19, yang berdampak pada buruknya kondisi kesehatan mental masyarakat (Saxena, 2016; World Health Organization, 2020a).

Situasi pandemi COVID-19 mendorong pembahasan yang lebih serius mengenai masifikasi pelayanan kesehatan mental, sebagai salah satu isu penting di dunia. Gangguan kesehatan mental yang sering tersembunyi dari pandangan sesungguhnya memiliki spektrum yang luas (Mawarpury, dkk., 2018). WHO telah mengidentifikasi kesehatan mental sebagai komponen integral dari penanggulangan COVID19 (World Health Organization, 2020b). Melihat permasalahan kesehatan mental dalam konteks situasi pandemi COVID-19, maka artikel ini berupaya untuk membahas bagaimana situasi global kebijakan kesehatan mental, serta bagaimana kebijakan dan upaya pemerintah Indonesia merespon beberapa permasalahan yang sedang dan akan terjadi sebagai akibat dari pandemi COVID-19.

\section{Masalah Kesehatan Mental dan Pandemi COVID-19 di Dunia}

Sebenarnya situasi pandemi global dan beberapa studi kejadian kesehatan di dunia dapat ditelusuri melalui beberapa kejadian wabah, yang salah satunya di Singapura pada tahun 2003. Saat itu, terdapat laporan yang menjelaskan bahwa 27 persen petugas kesehatan mengalami gejala gangguan kesehatan mental. Petugas medis di unit gawat darurat di Taiwan juga mengalami Post-Traumatic Stress Disorder (PTSD) (Lee, dkk., 2018). Gejala gangguan stres pasca wabah di Korea pada tahun 2015 juga dialami oleh staf medis yang melakukan tugas penanganan wabah MERS (Kim, dkk., 2019). Demikian pula, selama wabah Ebola di Sierra Leone pada tahun 2014 serta wabah yang sama di tahun 2018 di Republik Demokratik Kongo, dimana terdapat laporan mengenai tingginya tingkat kecemasan dan dampak stigma pada petugas yang melakukan kontak langsung dengan pasien yang terinfeksi (Cohn \& Kutalek, 2016; Park, dkk., 2018).

Selama wabah MERS-CoV Korea pada tahun 2015, stigma dan kekerasan berdampak langsung pada kesehatan mental tenaga kesehatan yang bekerja di rumah sakit umum (Torales, dkk., 2020). Dalam kondisi darurat COVID-19, tenaga medis di Wuhan telah mengalami risiko tinggi untuk terpapar infeksi COVID-19, dikombinasikan dengan situasi kerja yang tidak memadai dalam mengurangi bahaya kontaminasi, beban kerja yang berlebihan, perasaan frustasi, diskriminasi, perasaan terisolasi, kurangnya dukungan kontak dari keluarga dan kelelahan dapat meningkatkan risiko terjadinya gangguan kesehatan mental (Behanova, dkk., 2013; Park, dkk., 2018). Masalah kesehatan mental yang terjadi pada petugas medis dan kesehatan tidak hanya mempengaruhi kualitas pelayanan dan kapasitas pengambilan keputusan yang dapat menghambat upaya penanganan COVID-19, namun secara khusus juga memiliki efek yang bertahan lama pada kesejahteraan mereka secara keseluruhan. 
Situasi sulit di tengah pandemi semakin buruk akibat minimnya akses pelayanan kesehatan mental yang berkualitas. Di Amerika Serikat, upaya untuk membakukan pengukuran kualitas perawatan kesehatan mental dinilai lambat. Hanya sepertiga dari pelayanan kesehatan yang menerima perawatan kesehatan mental yang memadai. Kualitas pelayanan lamban ditingkatkan dibandingkan dengan perawatan medis umum. Kesenjangan kualitas perawatan kesehatan mental sebagian juga disebabkan oleh kurangnya metode sistematis untuk mengukur kualitas pelayanan kesehatan mental (Kilbourne, dkk., 2018). Kualitas perawatan kesehatan mental merupakan tantangan di seluruh dunia, karena dapat kondisinya amat bervariasi berdasarkan kebijakan layanan di setiap negara. Namun secara umum, relatif sedikit orang di seluruh dunia yang memiliki akses ke layanan kesehatan mental yang berkualitas.

Di negara berpenghasilan rendah dan menengah, lebih dari 75 persen orang dengan gangguan mental, neurologis, dan penyalahgunaan zat tidak menerima pengobatan sama sekali untuk kondisi mereka. Prevalensi Post-Traumatic Stress Disorder (PTSD) pada populasi umum berkisar antara 4 persen sampai 41 persen dan prevalensi depresi berat meningkat 7 persen setelah wabah (Kang, dkk., 2020). Meskipun beberapa studi cost-effectiveness melaporkan berkurangnya kecacatan terkait dengan kesehatan mental, namun hanya sebagian kecil dari mereka yang terkena dampak mendapatkan pengobatan yang tepat. Kesenjangan perawatan ini tampak sangat lebar di negara-negara berpenghasilan rendah atau menengah, yaitu sekitar 85 persen dari populasi dunia (Bruckner, dkk., 2011)

Meskipun masalah kesehatan mental kian memburuk di era pandemi, namun investasi dalam penanggulangannya tidak ada peningkatan yang berarti, yang ditandai dengan kurangnya sumber daya dan layanan serta adanya kesenjangan pengobatan yang besar dan kurangnya sumber daya. Konsekuensi langsung dan tidak langsung dari pandemi COVID-19 dapat berdampak pada peningkatan pelayanan di fasilitas kesehatan. Sistem kesehatan di dunia mendapatkan tantangan karena peningkatan kasus kesehatan mental dan penambahan jumlah kelompok rentan. Gangguan kesehatan mental yang sudah ada sebelumnya meningkatkan risiko keparahan penyakit dan kematian. Lebih lanjut, peningkatan gangguan kecemasan akibat takut terinfeksi, sakit, kehilangan anggota keluarga, serta kelompok rentan secara sosial dan ekonomi menjadi masalah kesehatan mental yang dampaknya kemungkikan terasa secara jangka panjang. Hal ini membutuhkan kebijakan pencegahan secara sistematis oleh semua negara (Behanova, dkk., 2013; World Health Organization, 2020a).

\section{Tantangan Kesehatan Mental di Indonesia di Masa Pandemi COVID-19}

Kebijakan kesehatan mental di Indonesia terbilang mengalami kemajuan apabila dibandingkan dengan beberapa dekade sebelumnya, meskipun kemajuannya cenderung lambat. Perumusan kebijakan kesehatan mental belum didukung oleh data penunjang yang adekuat, sama halnya seperti yang dialami banyak negara berkembang lainnya. Padahal data yang berkualitas sangat dibutuhkan untuk merumuskan kebijakan yang efektif sehingga pada tingkat pelayanan kesehatan primer dan sekunder upaya penanganan kesehatan mental dapat lebih optimal (Ridlo \& Zein, 2015).

Menilik Riset Kesehatan Dasar (Riskesdas) tahun 2018, menemukan 14 persen keluarga yang melakukan kurungan, dengan 31,5 persen melakukannya dalam 3 bulan terakhir. Data WHO pada 2017 menunjukkan tingkat psikiater 0,31, tingkat perawat kesehatan mental 2,52, dan pekerja sosial menilai 0,17 (semua per 100.000 populasi) mengkonfirmasi kurangnya sumber daya kesehatan mental di Indonesia. Disability Adjusted Life Years (DALY) mencapai 2.463,29 per 100.000 populasi dan tingkat kematian bunuh diri 3,4 tanpa strategi terkait pencegahan bunuh diri ditemukan. Prevalensi nasional depresi di antara orang-orang $\geq 15$ tahun mencapai 6,1 persen dengan hanya 9 persen dari mereka yang menerima perawatan dari para profesional (Kementerian Kesehatan RI, 2019). Peningkatan masalah 
kesehatan jiwa ini menunjukkan perlunya perhatian khusus terhadap kesehatan mental masyarakat Indonesia.

Seperti di banyak negara lainnya, pandemi COVID-19 membawa banyak perubahan bagi masyarakat. Pandemi COVID-19 dengan transmisi penularan yang masif dan tingkat kematian yang tinggi menyebabkan masalah yang mengarah pada gangguan kesehatan mental. Hal ini disebabkan oleh adanya kebiasaan baru yang wajib dilakukan oleh masyarakat, yaitu melakukan pembatasan sosial. Selain berdampak langsung pada petugas medis dan kesehatan, peningkatan kasus gangguan kesehatan mental juga dirasakan oleh masyarakat. Permasalahan yang sering terjadi diantaranya gejala kecemasan, depresi dan trauma karena COVID-19. Pada Juli 2020, kasus bunuh diri terjadi pada pasien COVID-19 di Surabaya, Jawa Timur dari lantai 6 Rumah Sakit karena depresi dikarenakan pasien tujuh kali melakukan swab dan hasilnya selalu positif terjadi (Antara, 2020; Pebriansyah, 2020). Kasus ini menjelaskan bahwa Pandemi COVID-19 pemicu permasalah kesehatan mental pada tahap yang memprihatinkan

Survei mengenai kesehatan mental melalui swaperiksa yang dihimpun oleh Perhimpunan Dokter Spesialis Kedokteran Jiwa Indonesia (PDSKJI) yang dilakukan secara daring menjelaskan bahwa sebanyak 63 persen responden mengalami cemas dan 66 persen responden mengalami depresi akibat pandemi COVID-19. Gejala cemas utama adalah merasa khawatir sesuatu yang buruk akan terjadi, khawatir berlebihan, mudah marah, dan sulit rileks. Sementara gejala depresi utama yang muncul adalah gangguan tidur, kurang percaya diri, lelah, tidak bertenaga, dan kehilangan minat. Lebih lanjut, sebanyak 80 persen responden memiliki gejala stres pasca trauma psikologis karena mengalami atau menyaksikan peristiwa tidak menyenangkan terkait COVID-19. Gejala stres pasca trauma psikologis berat dialami 46 persen responden, gejala stres pasca trauma psikologis sedang dialami 33 persen responden, gejala stres pasca trauma psikologis ringan dialami 2 persen responden, sementara 19 persen tidak ada gejala. Adapun gejala stres pascatrauma yang menonjol yaitu merasa berjarak dan terpisah dari orang lain serta merasa terus waspada, berhati-hati, dan berjaga-jaga (Perhimpunan Dokter Spesialis Kesehatan Jiwa Indonesia, 2020). Setidaknya terdapat empat faktor risiko utama depresi dari 14 yang umumnya ditemui, yang muncul akibat pandemi COVID-19, yaitu isolasi dan social distancing, tekanan ekonomi, stres dan depresi pada tenaga kesehatan dan stigma dan diskriminasi (Thakur \& Jain, 2020)

Menjaga jarak fisik (physical distancing) menimbulkan banyak kecemasan masyarakat. Namun pada kasus ini kerentanan terjadi pada masyarakat yang mempunyai risiko depresi dan individu yang hidup dalam kesendirian. Perasaan terasing akibat menjaga jarak sosial dan isolasi mandiri telah mengganggu aktivitas normal (Megatsari, dkk., 2020). Pandemi COVID-19 telah memicu krisis ekonomi global yang kemungkinan akan meningkatkan risiko bunuh diri terkait dengan pengangguran dan tekanan ekonomi. Perasaan ketidakpastian, putus asa, dan tidak berharga meningkatkan angka bunuh diri. Di Kota Tangerang, contohnya, Seorang pemuda berusia 20 tahun bunuh diri diduga karena pekerjaan tempat bekerja tidak beroperasi terdampak situasi pandemi COVID-19 (Singgih, 2020), pertumbuhan ekonomi yang menurun drastis hingga minus 5,32\% pada kuartal II 2020 berakibat pada kemungkinan Indonesia masuk ke jurang ekonomi (Bramasta, 2020).

Stres dan trauma pada tenaga kesehatan juga menjadi isu penting di Indonesia. Pengalaman global tentang kasus kesehatan mental di Korea, Singapura, Taiwan dan beberapa negara lainnya membuat pelayanan kesehatan menjadi terganggu (Jeong, dkk., 2016; Kang, dkk., 2020; Park, dkk., 2018). Potensi depresi dan kasus bunuh diri pada tenaga medis dan kesehatan juga seharusnya menjadi prioritas. Selain itu stigma dan diskriminasi juga menjadi bagian lain selain risiko tugas yang harus ditanggung oleh tenaga medis dan kesehatan. Stigma dan diskriminasi ini mempunyai risiko jangka panjang terhadap kesehatan (National Collaborating Centre for Determinants of Health (NCCDH), 2020). Di 
Indonesia, stigma dan diskriminasi dialami secara nyata, terutama oleh tenaga kesehatan. Bentuk stigma yang dialami antara lain berupa orang-orang sekitar menghindar dan menutup pintu saat melihat perawat, diusir dari tempat tinggal, dilarang naik kendaraan umum, keluarga dikucilkan, dilarang menikahi mereka, dan ancaman diceraikan oleh suami atau istri ("Benahi Perlindungan terhadap", 2020).

\section{Upaya Pemerintah dalam Memperkuat Kebijakan Kesehatan Mental}

Sejak ditetapkan Undang-Undang Nomor 18 tahun 2014 tentang Kesehatan Jiwa, sejumlah masalah, baik pada perumusan beberapa peraturan turunan dan dukungan pemerintah daerah, masih belum dapat terselesaikkan (Ayuningtyas, dkk., 2018; Ridlo \& Zein, 2015). Dalam situasi pandemi COVID-19 pemerintah melalui Keputusan Presiden RI Nomor 7 tahun 2020 yang kemudian direvisi dalam Keputusan Presiden RI Nomor 9 tahun 2020, Pemerintah mengeluarkan kebijakan yang berisi tentang pembentukan gugus tugas percepatan penanganan COVID-19. Isi Keputusan Presiden tersebut menjadi dasar kebijakan pada implikasi sosial, ekonomi, dan kesejahteraan masyarakat.

Sebagai upaya preventif, pemerintah berupaya menanggulangi dampak pandemi COVID-19, khususnya untuk kesehatan mental, dengan menyusun pedoman dukungan kesehatan jiwa dan psikososial pada pandemi COVID-19. Pedoman ini mengacu pada kebijakan WHO, serta diharapkan dapat menjadi acuan bagi pemerintah daerah untuk mengambil langkah pencegahan, penanganan kasus kesehatan mental. Selain itu, pemerintah juga bekerja sama dengan Himpunan Psikologi Indonesia (HIMPSI) dalam memberikan layanan Sejiwa untuk membantu masyarakat dalam mengatasi gangguan psikologis akibat pandemi COVID-19 (Taher, 2020). Layanan ini bertujuan untuk memberikan edukasi publik, konsultasi publik, konsultasi awal kejiwaan dan pendamping dalam menangani potensi gangguan kesehatan mental bagi masyarakat yang terdampak pandemi COVID-19.

Dalam upaya intervensi program kesehatan mental di masa pandemi COVID-19, penting untuk melibatkan masyarakat sebagai bagian dari aktor kebijakan. Dalam penanganan pandemi mengoptimalisasi komunikasi dengan masyarakat dan pelibatan masyarakat sebagai subjek kebijakan harus dilakukan (Kutalek, dkk., 2015). Oleh karena itu, Kementerian Kesehatan menginisiasi program Desa Siaga yang dicanangkan pada tahun 2018 dan bertujuan meningkatkan kesiapan sumber daya dan kemampuan serta kemauan untuk mencegah dan mengatasi masalah kesehatan, bencana dan kegawatdaruratan kesehatan secara mandiri (Kementerian Kesehatan RI, 2018). Potensi adanya program desa siaga tersebut kemudian diadopsi oleh Kementerian Desa, Pembangunan Daerah Tertinggal dan Transmigrasi Daerah Tertinggal menjadi desa tanggap COVID-19 diperkuat dengan surat edaran No. 5 tahun 2020 tentang desa tanggap COVID-19 dan penegasan padat karya tunai desa. Walaupun program ini belum menyentuh permasalahan Kesehatan mental secara langsung, namun dibutuhkan advokasi lebih khusu sehingga potensi desa tanggal COVID-19 ini dapat membantu penanggulangan gangguan Kesehatan mental pada skala komunitas.

Berdasarkan kebijakan penanggulangan COVID-19 dan sejumlah protokol yang sudah dibuat, maka pemerintah harus mengoptimalisasi integrasi layanan kesehatan mental yang sudah ada dalam sistem kesehatan nasional (Jeong, dkk., 2016; Ridlo \& Zein, 2015). Utamanya dengan pendekatan berbasis kesehatan masyarakat dan memperkuat pelayanan kesehatan primer (Megatsari, dkk., 2019). Upaya tersebut dapat memperluas cakupan pelayanan kesehatan mental yang sangat diperlukan utamanya pada masa pandemi COVID-19. Cakupan pelayanan kesehatan bagi seluruh masyarakat yang berkeadilan akan mendorong kepercayaan publik terhadap penanganan Pandemi COVID-19 (Ayuningtyas, dkk., 2018; Sumiharti \& Laksono, 2013; Zein, dkk., 2020). 


\section{S I M P U L A N}

Kebijakan kesehatan mental merupakan bagian penting dari kebijakan percepatan penanggulangan pandemi COVID-19. Masalah kesehatan mental sangat berkaitan dengan hilangnya produktivitas masyarakat dan juga pengendalian pandemi COVID-19. Jika pemerintah tidak memberikan perhatian yang diperlukan pada isu kesehatan mental, khususnya dalam intergrasi implementasi kebijakan terkait penanggulangan pandemi COVID-19, maka potensi kerugian paskapandemi akan semakin besar. Pemerintah harus mengintegrasikan layanan kesehatan mental ke dalam layanan berbasis masyarakat sebagai cara untuk memastikan cakupan universal layanan kesehatan mental. Model pemberdayaan partisipatif dan bottom-up menjadi pilihan yang rasional untuk mengatasi masalah sumber daya dan stigma sebagai penghalang keberhasilan program kesehatan mental di Indonesia.

\section{U C A P A N T ERIMAKASIH}

Penulis menyampaikan terimakasih kepada para peneliti The Airlangga Centre for Health Policy (ACeHAP RG) Fakultas Kesehatan Masyarakat Universitas Airlangga sebagai kelompok riset yang mempunyai perhatian terhadap isu kesehatan mental.

\section{DEKLARASI POTENSI TERJADINYAKONFLIK KEPENTINGAN}

Ilham Akhsanu Ridlo tidak bekerja, menjadi konsultan, memiliki saham, atau menerima dana dari perusahaan atau organisasi manapun yang mungkin akan mengambil untung dari diterbitkannya naskah ini.

\section{PUSTAKA ACUAN}

Antara. (2020). Pasien Positif COVID-19 di RSU Haji Surabaya Diduga Bunuh Diri. Diunduh dari: Tirto.id. https://tirto.id/pasien-positif-covid-19-di-rsu-haji-surabaya-diduga-bunuh-diri-fUCe

Ayuningtyas, D., Misnaniarti, M., \& Rayhani, M. (2018). Analisis Situasi Kesehatan Mental pada Masyarakat di Indonesia dan Strategi Penanggulangannya. Jurnal Ilmu Kesehatan Masyarakat, 9(1). https://doi.org/10.26553/jikm.2018.9.1.1-10

Behanova, M., Nagyova, I., Katreniakova, Z., van Ameijden, E. J. C., van Dijk, J. P., \& Reijneveld, S. A. (2013). The effect of urban-area unemployment on the mental health of citizens differs between Slovak and Dutch cities. Heath \&. Place, 24, 210-215. https://doi.org/10.1016/j.healthplace.2013.09.013

Benahi Perlindungan terhadap Tenaga Kesehatan. (2020, April 20). Kompas.id. https://kompas.id/baca/bebas-akses/2020/04/20/benahi-perlindungan-terhadap-tenagakesehatan/

Bramasta, D.B. (2020). Siap-siap Resesi Ekonomi, Ini Dampak dan Cara Mengatasinya. Diunduh dari: KOMPAS.com. October 23, 2020, from https://www.kompas.com/tren/read/2020/09/23/123000565/siap-siap-resesi-ekonomi-inidampak-dan-cara-mengatasinya-

Bruckner, T. A., Scheffler, R. M., Shen, G., Yoon, J., Chisholm, D., Morris, J., Fulton, B. D., Dal Poz, M. R., \&

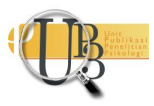


Saxena, S. (2011). The mental health workforce gap in low- and middle-income countries: A needsbased approach. Bulletin of the World Health Organization, 89(3), 184-194. https://doi.org/10.2471/BLT.10.082784

Cohn, S., \& Kutalek, R. (2016). Historical Parallels, Ebola Virus Disease and Cholera: Understanding Community Distrust and Social Violence with Epidemics. PLoS Currents. https://doi.org/10.1371/currents.outbreaks.aa1f2b60e8d43939b43fbd93e1a63a94

Corman, V. M., Landt, O., Kaiser, M., Molenkamp, R., Meijer, A., Chu, D. K., Bleicker, T., Brünink, S., Schneider, J., Schmidt, M. L., Mulders, D. G., Haagmans, B. L., van der Veer, B., van den Brink, S., Wijsman, L., Goderski, G., Romette, J.-L., Ellis, J., Zambon, M., ... Drosten, C. (2020). Detection of 2019 novel coronavirus (2019-nCoV) by real-time RT-PCR. Eurosurveillance, 25(3). https://doi.org/10.2807/1560-7917.ES.2020.25.3.2000045

Cui, J., Li, F., \& Shi, Z.-L. (2019). Origin and evolution of pathogenic coronaviruses. Nature Reviews Microbiology, 17(3), 181-192. https://doi.org/10.1038/s41579-018-0118-9

Gao, J., Zheng, P., Jia, Y., Chen, H., Mao, Y., Chen, S., Wang, Y., Fu, H., \& Dai, J. (2020). Mental health problems and social media exposure during COVID-19 outbreak. PLOS ONE, 15(4), e0231924. https://doi.org/10.1371/journal.pone.0231924

Huang, C., Wang, Y., Li, X., Ren, L., Zhao, J., Hu, Y., Zhang, L., Fan, G., Xu, J., Gu, X., Cheng, Z., Yu, T., Xia, J., Wei, Y., Wu, W., Xie, X., Yin, W., Li, H., Liu, M., ... Cao, B. (2020). Clinical features of patients infected with 2019 novel coronavirus in Wuhan, China. The Lancet, 395(10223), 497-506. https://doi.org/10.1016/s0140-6736(20)30183-5

Jeong, H., Yim, H. W., Song, Y.-J., Ki, M., Min, J.-A., Cho, J., \& Chae, J.-H. (2016). Mental health status of people isolated due to Middle East Respiratory Syndrome. Epidemiology and Health, 38, e2016048. https://doi.org/10.4178/epih.e2016048

Kang, L., Li, Y., Hu, S., Chen, M., Yang, C., Yang, B. X., Wang, Y., Hu, J., Lai, J., Ma, X., Chen, J., Guan, L., Wang, G., Ma, H., \& Liu, Z. (2020). The mental health of medical workers in Wuhan, China dealing with the 2019 novel coronavirus. The Lancet Psychiatry, 7(3), e14. https://doi.org/10.1016/s22150366(20)30047-x

Kementerian Kesehatan RI. (2018, June 28). DESA SIAGA. Direktorat Promosi Kesehatan Kementerian Kesehatan RI. https://promkes.kemkes.go.id/desa-siaga

Kementerian Kesehatan RI. (2019). Riset Kesehatan Dasar (RISKESDAS) 2018. Lembaga Penerbit Badan Penelitian dan Pengembangan Kesehatan. Diunduh dari: http://labdata.litbang.kemkes.go.id/images/download/laporan/RKD/2018/Laporan_Nasional_ RKD2018_FINAL.pdf

Kilbourne, A. M., Beck, K., Spaeth-Rublee, B., Ramanuj, P., O’Brien, R. W., Tomoyasu, N., \& Pincus, H. A. (2018). Measuring and improving the quality of mental health care: A global perspective. World Psychiatry, 17(1), 30-38. https://doi.org/10.1002/wps.20482

Kim, Y. G., Moon, H., Kim, S.-Y., Lee, Y.-H., Jeong, D.-W., Kim, K., Moon, J. Y., Lee, Y.-K., Cho, A., Lee, H.-S., Park, H. C., \& Lee, S.-H. (2019). Inevitable isolation and the change of stress markers in hemodialysis patients during the 2015 MERS-CoV outbreak in Korea. Scientific Reports, 9(1), 5676. https://doi.org/10.1038/s41598-019-41964-x

Kutalek, R., Wang, S., Fallah, M., Wesseh, C. S., \& Gilbert, J. (2015). Ebola interventions: Listen to communities. The Lancet Global Health, 3(3), e131. https://doi.org/10.1016/s2214- 


\section{$109 x(15) 70010-0$}

Lee, S. M., Kang, W. S., Cho, A.-R., Kim, T., \& Park, J. K. (2018). Psychological impact of the 2015 MERS outbreak on hospital workers and quarantined hemodialysis patients. Comprehensive Psychiatry, 87, 123-127. https://doi.org/10.1016/j.comppsych.2018.10.003

Mawarpury, M., Rosemary, R., \& Sebayang, S. K. (2018, November 2). 260 juta orang dan kurang dari 1000 psikiater, Indonesia kekurangan pekerja kesehatan mental. The Conversation. http://theconversation.com/260-juta-orang-dan-kurang-dari-1000-psikiater-indonesiakekurangan-pekerja-kesehatan-mental-105969

Megatsari, H., Laksono, A. D., Ibad, M., Herwanto, Y. T., Sarweni, K. P., Geno, R. A. P., \& Nugraheni, E. (2020). The community psychosocial burden during the COVID-19 pandemic in Indonesia. Heliyon, 6(10), e05136. https://doi.org/10.1016/j.heliyon.2020.e05136

Megatsari, H., Ridlo, I. A., Yoto, M., Abdul Jabbar, N., Nur Azizah, A., Ainurrohman, M., Prayitno, J., Husnia, Z., Andzar Ridwanah, A., Sarweni, K. P., Esvanti, M., Irfan Hadi, M., \& Laksono, A. D. (2019). Connecting the unconnected: Riset aksi partisipatif desa sehat berdaya. Health Advocacy - Yayasan Pemberdayaan Kesehatan Masyarakat.

National Collaborating Centre for Determinants of Health (NCCDH). (2020). Stigma, discrimination, health impacts and COVID-19. https://nccdh.ca/blog/entry/stigma-discrimination-healthimpacts-and-covid-19

Park, J.-S., Lee, E.-H., Park, N.-R., \& Choi, Y. H. (2018). Mental Health of Nurses Working at a Governmentdesignated Hospital During a MERS-CoV Outbreak: A Cross-sectional Study. Archives of Psychiatric Nursing, 32(1), 2-6. https://doi.org/10.1016/j.apnu.2017.09.006

Pebriansyah, A. (2020, July 30). Pasien Corona RS Haji Surabaya Bunuh Diri, Lompat dari Lantai 6. Suara.com. Diunduh dari: https://jatim.suara.com/read/2020/07/30/170332/pasien-coronars-haji-surabaya-bunuh-diri-lompat-dari-lantai-6

Perhimpunan Dokter Spesialis Kesehatan Jiwa Indonesia. (2020, October 23). 5 bulan pandemi COVID19 di Indonesia. Perhimpunan Dokter Spesialis Kesehatan Jiwa Indonesia. Diunduh dari: http://pdskji.org/home

Pfefferbaum, B., \& North, C. S. (2020). Mental Health and the Covid-19 Pandemic. New England Journal of Medicine, 383(6), 510-512. https://doi.org/10.1056/nejmp2008017

Ridlo, I. A., \& Zein, R. A. (2015). Arah Kebijakan Kesehatan Mental: Tren Global dan Nasional serta Tantangan Aktual. Buletin Penelitian Kesehatan. https://doi.org/10.22435/bpk.v46i1.4911.45-52

Saxena, S. (2016). Challenges and opportunities in global mental health: A perspective from WHO. Epidemiology and Psychiatric Science, 25(6). https://doi.org/10.1017/S2045796016000536

Singgih, W. (2020, May 18). Pemuda Berusia 20 Tahun Ditemukan Tewas di Kontrakan, Diduga Bunuh Diri. KOMPAS.com. Diunduh dari: https://megapolitan.kompas.com/read/2020/05/18/06284801/pemuda-berusia-20-tahunditemukan-tewas-di-kontrakan-diduga-bunuh-diri

Spoorthy, M. S., Pratapa, S. K., \& Mahant, S. (2020). Mental health problems faced by healthcare workers due to the COVID-19 pandemic-A review. Asian Journal of Psychiatry, 51, 102119. https://doi.org/10.1016/j.ajp.2020.102119

Sumiharti, \& Laksono, A. D. (2013). Review Kebijakan Tentang Pelayanan Kesehatan Puskesmas di

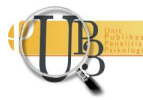


Daerah Terpencil Perbatasan. Buletin Penelitian Sistem Kesehatan, 16, 109-116.

Taher, A. P. (2020, April 29). Pemerintah Luncurkan Layanan Konseling Psikologi Bernama Sejiwa. Tirto.id. Diunduh dari: https://tirto.id/pemerintah-luncurkan-layanan-konseling-psikologibernama-sejiwa-feRV

Thakur, V., \& Jain, A. (2020). COVID 2019-suicides: A global psychological pandemic. Brain, Behavior, and Immunity, 88, 952-953. https://doi.org/10.1016/j.bbi.2020.04.062

Torales, J., O’Higgins, M., Castaldelli-Maia, J. M., \& Ventriglio, A. (2020). The outbreak of COVID-19 coronavirus and its impact on global mental health. The International Journal of Social Psychiatry, 66(4), 317-320. https://doi.org/10.1177/0020764020915212

World Health Organization. (2020a). World Mental Health Day: An opportunity to kick-start a massive scale-up in investment in mental health. https://www.who.int/news/item/27-08-2020-worldmental-health-day-an-opportunity-to-kick-start-a-massive-scale-up-in-investment-in-mentalhealth

World Health Organization. (2020b). Novel Coronavirus(2019-nCoV) Situation Report. https://www.who.int/docs/default-source/coronaviruse/situation-reports/20200202-sitrep13-ncov-v3.pdf

Zein, R. A., Putri, N. K., \& Ridlo, I. A. (2020). Do justice and trust affect acceptability of Indonesian social health insurance policy? International Journal of Health Governance, 25(1), 78-92. https://doi.org/10.1108/IJHG-05-2019-0028 